\title{
The Financial Implications Of Bodaboda Transport Business Among Youths In Arusha- Cost Benefit Analysis
}

\author{
Kepha C. Luvinga \\ Department of Project Planning and Management \\ Tengeru Institute of Community Development, Tanzania. \\ Simon A. Kilasara \\ Department of Project Planning and Management, \\ Tengeru institute of Community Development, Tanzania.
}

\begin{abstract}
This study reports upon the findings on the cost and profitability of bodaboda transport business among youths in Arusha. As used in this study, the term bodaboda applies for a two wheeled motorized taxi which provides 'for hire' type transport services to passengers and goods. The bodaboda have became an employment opportunity to many unskilled urban labour and further job opportunity to informal sector workers who wish to switch jobs in search of higher rewards. The questionnaires were used to collect data to 90 respondents from two districts of Arusha region namely Arusha and Meru district. Data analysis was done using descriptive statistics and cost benefit analysis. The finding from the study indicates that the bodaboda transport business is profitable with the benefit cost ratio (BCR) of 2.8 and the net present value (NPV) of $8,494,920$ Tsh for five years project duration.

By having the benefit cost ratio and the net present value greater than 1 , the bodaboda business is profitable and worth being undertaken. Based on the findings from the study it is recommended that the government authorities and all key stakeholders should regulate, and support the implementation of bodaboda bussiness through formalization of bodaboda associations, assurance of financial supports and capacity building to youths who engage or willing to engage in the business.
\end{abstract}

\section{INTRODUCTION}

There has been an increasing and significant growth in the use of motorcycles as a commercial public transport mode in Sub-Saharan Africa, Latin America and Asia, (Kumar, 2011). In East Africa, Bodaboda transport service is a Ugandan innovation that has grown from small beginnings in the late 1960s at Busia in the Kenya-Uganda border (Malmberg, 1994).Various names are given to this business depending on the areas of operations and the history and culture of the users. In Rwanda these motorcycles are known as "moto" and are majorly operated by the youth aged between 18-35 years (Summers, 2012). According to Kumar (2011) In Nigeria, the use of motorcycle in transport business is known as Okada which is coined from the famous airline named Okada while in Ghana it is known as bendskin and in most parts of East Africa it is known as bodaboda. 
Luvinga, K. C., \& Kilasara, S. A. (2020). The Financial Implications of Bodaboda Transport Business Among Youths In Arusha- Cost Benefit Analysis. Advances in Social Sciences Research Journal, 7(4) 177-185.

According to Olvera, Plat \& Potchet (2009), a motorbike is acquired from personal income, family aid or even from personal financing networks. Kumar (2011) asserts that, ease of entry, low capital requirement, employment potential, and ability to navigate congested and poor quality roads with relative ease are some of the factors contributing to the growth of commercial motorcycles. Nyachieo (2013) relates the growth of Bodaboda commercial transport with the increasing demand of employment opportunities. Kageha and Agesa (2006) argue that the bodaboda transport business is assuming a vital role in transportation of goods and services therefore they contribute to the economy of the Nations. Transport sector is an important component of the economy impacting on development and the welfare of populations, (Mbugua 2011).

Booth, Hanmer, and Lovell, (2000) documents that, livelihood outcomes attained by the youths result from their use of assets. Bodaboda transport services are part of both the community's asset base that has impacts to community livelihood.

\section{Problem Statement}

There has been an increasing demand of transportation in most of the urban areas worldwide. Kumar (2011) documents that private vehicle ownership is low to the individuals in developing cities therefore dependence on public transport is high. This situation has forced people and the market to develop creative solutions to address daily travel needs. A search for these alternatives has led to rapid growth in non conventional means of public transport, initially provided by minibuses and shared taxi/vans, and more recently by commercial motorcycles.

According to Howe and Davis (2002), Bodaboda primarily provide services within the main urban areas where they compete with conventional sole hire taxis and minibuses (Matatu in Kenya and Daladala in Tanzania), they also provide services as feeders to urban areas on routes that have either low population density or very rough and unattractive for taxis and minibuses to operate.

In the last fifteen years the numbers of motorcycles per capita in many Developing Asian nations has doubled (World Bank, 2002). The bodaboda business has became an alternative economic opportunity for youths livelihoods after experiencing negative rewards from agricultural activities and other economic activities for several years up to date (Salum, 2015).According to Mbugua (2011) with the lure of quick monetary gains on a daily basis, majority of the urban and peri urban poor have embraced this mode of transport as a household solution to their livelihoods through widened employment opportunity.

Despite the business employing many youths in Tanzania little is known about the cost and profitability of the business. Therefore the objective of this paper is to examine the cost and profitability of the bodaboda business to youths engaging in the business.

The findings of the study are expected to contribute to the debate on the contribution of the commercial motorcycle transport sub-sector towards household's income and livelihood, thereby expanding the frontier of knowledge in this area. 


\section{METHODOLOGY}

\section{Research Design}

To achieve the objective the study used cross section study design and therefore it employed the use of one short study design in order to find out the profitability of bodaboda business among youths

\section{Area of study and Sampling}

Significantly, this study was carried out in Arusha region but its scope of operation will not necessarily be limited to Arusha. The study population composed of youth's population engaging in bodaboda commercial transport.

The selection of the sample involved a triangulation of both purposive and random sampling technique to select individual respondents from the population. Being that, the sample of 90 respondents was used. The study considered it to be rational to use purposive sampling to identify respondents who could relatively account conversantly in respect of their undertakings in relation to the study on bodaboda commercial transport who were randomly selected from their customer waiting stations. The primary data were collected through the use of questionnaires and schedules designed for studying the cost and profitability of bodaboda business to the youths.

\section{Data analysis methods.}

Through simplifications upon the use of statistical package for social science (SPSS), the study involved the use of descriptive statistics for the analysis of the costs and profitability of bodaboda transport subsector among youths. The profitability of bodaboda business was further analyzed and presented using the Discounted Cost benefit analysis techniques including the Benefit Cost ratio and the Net present Value.

$$
B C R=\frac{\text { Sum of the Discounted Benefits }}{\text { Sum of the Discounted Costs }}
$$

The use of Net Present Value was also sought to be more important in assessing the viability and profitability of the bodaboda transport subsector in five years duration. The study used the $20 \%$ market discount rate (r) which is commonly used by Tanzania banks where by the decision on the duration of the project was based on an assumption that the life span for a motorcycle is 5 years.

$$
N P V=\sum_{i=1}^{n} \frac{B_{i}-C_{i}}{(1+r)^{i}}
$$

Where,

NPV $=$ Net Present Value,

$\mathrm{r}=$ discount rate,

$\mathrm{n}=$ specific year in project duration,

$\mathrm{B}=$ benefits,

$\mathrm{C}=$ costs. 
Luvinga, K. C., \& Kilasara, S. A. (2020). The Financial Implications of Bodaboda Transport Business Among Youths In Arusha- Cost Benefit Analysis. Advances in Social Sciences Research Journal, 7(4) 177-185.

\section{Respondents sex}

\section{RESULTS AND DISCUSSION}

The findings presented in Table 3.1 shows that $97.8 \%$ are male and $2.2 \%$ of the youths engaging in the business are females. This suggests that there is an opportunity for both males and females to engage in bodaboda transport business.

Table 3.1 Respondents Sex

\begin{tabular}{|c|c|c|c|}
\hline Item & Sex Category & Frequency & Percentage \\
\hline \multirow{3}{*}{$\begin{array}{c}\text { Sex Of } \\
\text { Respondents }\end{array}$} & Male & 88 & 97.8 \\
\cline { 2 - 4 } & Female & 2 & 2.2 \\
\cline { 2 - 4 } & Total & $\mathbf{9 0}$ & $\mathbf{1 0 0 . 0}$ \\
\hline
\end{tabular}

Source: Study Findings (2015)

\section{Age of respondents}

The findings from the study reveals that $37.8 \%$ of the youths engaging in bodaboda business are aged between $19-24$ years, $30 \%$ are aged $25-29$ years and $17.8 \%$ of the youths engaging in bodaboda business were aged 30-34 years old.

Table 3.2 Age of respondents

\begin{tabular}{|c|c|c|c|}
\hline \multirow{2}{*}{ Item } & Age Category & Frequency & Percentage \\
\hline \multirow{4}{*}{$\begin{array}{c}\text { Age Of } \\
\text { Respondents }\end{array}$} & $15-18$ yrs & 1 & 1.1 \\
\cline { 2 - 4 } & $19-24$ yrs & 34 & 37.8 \\
\cline { 2 - 4 } & $25-29 \mathrm{yrs}$ & 27 & 30.0 \\
\cline { 2 - 4 } & $30-34 \mathrm{yrs}$ & 16 & 17.8 \\
\cline { 2 - 4 } & $35-40 \mathrm{yrs}$ & 12 & 13.3 \\
\cline { 2 - 4 } & Total & $\mathbf{9 0}$ & $\mathbf{1 0 0 . 0}$ \\
\hline
\end{tabular}

\section{Marital status and household characteristics}

The findings from this study reveal that $55.6 \%$ of youths engaging in bodaboda business are married while $44.5 \%$ are not married. Among the respondents $77.8 \%$ are heads of their households while $22.2 \%$ of respondent's households are headed by their parents.

Table 3.3. Marital status and household characteristics

\begin{tabular}{|c|c|c|c|}
\hline Item & Item response & Frequency & Percentage \\
\hline \multirow{4}{*}{ Marital Status } & Married & 50 & 55.6 \\
\cline { 2 - 4 } & Never Married & 17 & 18.9 \\
\cline { 2 - 4 } & Not Married & 23 & 25.6 \\
\cline { 2 - 4 } & Total & $\mathbf{9 0}$ & $\mathbf{1 0 0 . 0}$ \\
\hline \multirow{2}{*}{ Item } & Item response & Frequency & 77.8 \\
\hline \multirow{3}{*}{ Household heads } & My self & 70 & 22.2 \\
\cline { 2 - 4 } & Parents & 20 & $\mathbf{1 0 0 . 0}$ \\
\cline { 2 - 4 } & Total & $\mathbf{9 0}$ & Percentage \\
\hline \hline
\end{tabular}

URL: http://dx.doi.org/10.14738/assrj.74.7998 


\section{Education Characteristics}

The findings from this study as presented in Table 3.4 reveals that $59 \%$ of the youths engaging in bodaboda business holds primary education, $34 \%$ have secondary education and $6 \%$ have college education. Only $1 \%$ of youths engaging in bodaboda business have higher/university education.

Table 3.4 Education Characteristics

\begin{tabular}{|c|c|c|c|}
\hline \multirow{2}{*}{ Item } & Status & Frequency & Percentage \\
\hline \multirow{4}{*}{$\begin{array}{c}\text { Level of } \\
\text { Education }\end{array}$} & Primary Ed & 53 & 59 \\
\cline { 2 - 4 } & Secondary Ed & 31 & 34 \\
\cline { 2 - 4 } & College Ed & 5 & 6 \\
\cline { 2 - 4 } & Higher Learning Ed & 1 & 1 \\
\cline { 2 - 4 } & Total & $\mathbf{9 0}$ & $\mathbf{1 0 0 . 0}$ \\
\hline
\end{tabular}

\section{Initial capital (Fixed costs)}

The findings on the initial cost for starting bodaboda business summarized in figure 3.1 below indicates that, $70 \%$ of the respondents started engaging in the business with less than 1 million Tanzania shillings, 25\% used 1-2 million Tanzania shillings for starting the business, $3 \%$ used 2-3 million Tanzania shillings to start the bodaboda business, $2 \%$ of the respondents used more than 3 million Tanzania shillings to start their business.

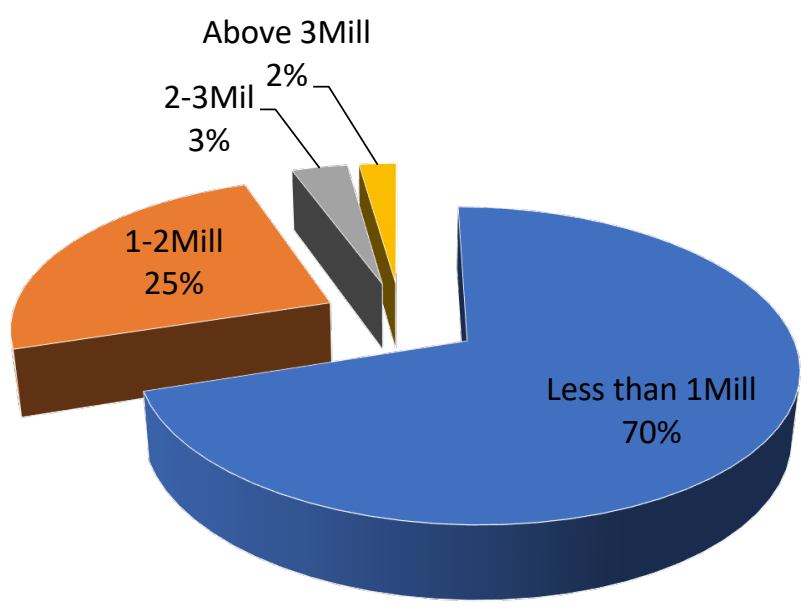

Source: Study findings (2015)

\section{Figure 3.1 Initial capital (Fixed costs) in Tsh}

\section{Monthly cost for repair and maintenance}

The findings as summarized in Table 3.6, shows that, $56.7 \%$ of the respondents use 21000Tsh30,000 Tsh per month for repair and maintenance of their motorcycles, 28.9 spend 11000Tsh20000 Tsh for monthly repair and maintenance, $10 \%$ spend 31,000Tsh - 40,000Tsh in repair and maintenance and $2.2 \%$ use more that 50,000Tsh per month for repair and maintenance of their motorcycles. 
Luvinga, K. C., \& Kilasara, S. A. (2020). The Financial Implications of Bodaboda Transport Business Among Youths In Arusha- Cost Benefit Analysis. Advances in Social Sciences Research Journal, 7(4) 177-185.

Table 3.6 Monthly cost for repair and maintenance

\begin{tabular}{|c|c|c|c|}
\hline \multirow{2}{*}{ Item } & Amount in Tsh & Frequency & Percent \\
\hline \multirow{4}{*}{$\begin{array}{c}\text { Repair and } \\
\text { Maintenance Cost }\end{array}$} & 11000-20000Tsh & 26 & 28.9 \\
\cline { 2 - 4 } & $21000-30000 T s h$ & 51 & 56.7 \\
\cline { 2 - 4 } & 31000-40000Tsh & 9 & 10 \\
\cline { 2 - 4 } & 41000-50000Tsh & 2 & 2.2 \\
\cline { 2 - 4 } & Above 50000Tsh & 2 & 2.2 \\
\hline
\end{tabular}

\section{Daily costs for fuel, lubricants and other bodaboda expenses}

The findings as summarized in Table 3.7, shows that, 45.6\% of respondents use 4000Tsh-6000Tsh daily for fuel, lubricants and other daily expenses, 33.3\% spend 2000Tsh-4000Tsh for daily operating activities, 8.9\% spend 6000Tsh-8000Tsh in daily operations and 7.8\% use more that 8000Tsh in daily bodaboda operations while 4.4\% use 1000Tsh -2000Tsh in their daily bodaboda operations.

Table 3.7 Daily cost in fuel, lubricants and other bodaboda operations costs.

\begin{tabular}{|c|c|c|c|}
\hline \multirow{1}{*}{ Item } & Amount in Tsh & Frequency & Percent \\
\hline \multirow{4}{*}{$\begin{array}{c}\text { Daily average cost for } \\
\text { fuel and other } \\
\text { operating costs }\end{array}$} & 1000-2000Tsh & 4 & 4.4 \\
\cline { 2 - 4 } & 2000-4000Tsh & 30 & 33.3 \\
\cline { 2 - 4 } & 4000-6000Tsh & 41 & 45.6 \\
\cline { 2 - 4 } & 6000-8000Tsh & 8 & 8.9 \\
\cline { 2 - 4 } & Above 8000Tsh & 7 & 7.8 \\
\hline
\end{tabular}

\section{Daily revenue from bodaboda business}

The findings on income from bodaboda reveals that $67.8 \%$ of respondents gets more than 15,000 Tsh daily revenue from bodaboda, 18.9\% get 10000Tsh-15000Tsh daily revenue from bodaboda, $11.1 \%$ get 5000 Tsh-10000Tsh daily revenue from bodaboda and $2.2 \%$ get less than 5000Tsh daily revenue from bodaboda.

Table 3.8 Daily revenue from bodaboda business

\begin{tabular}{|c|c|c|c|}
\hline \multirow{2}{*}{ Item } & Amount in Shillings & Frequency & Percent \\
\hline \multirow{3}{*}{$\begin{array}{c}\text { Daily Income } \\
\text { from Bodaboda }\end{array}$} & Less than 5000Tsh & 2 & 2.2 \\
\cline { 2 - 4 } & 5000-10000Tsh & 10 & 11.1 \\
\cline { 2 - 4 } & 10000-15000Tsh & 17 & 18.9 \\
\cline { 2 - 4 } & Above 15000Tsh & 61 & 67.8 \\
\hline
\end{tabular}




\section{Profitability of bodaboda business, Net Present Value (NPV) and Benefit Cost Ratio (BCR)}

The NPV and BCR were analyzed based on data on the cost and benefits in duration of 5 years using $20 \%$ discount rates used by Tanzania banks. The calculation of the NPV based on the findings on the initial capital for starting bodaboda business, annual repair and maintenance costs, the annual costs for fuel and other operating expenses. The annual income was also analyzed using the findings of the study. Based on the findings the average initial cost was 1,500,000 million Tanzania shillings, the annual average cost for repair and maintenance was approximated to be 306000Tsh, Fuel and other daily expenses was approximated to 1,830,000Tsh for the 366 days of the year. Also the findings indicated that the daily income in bodaboda business was approximated to 15,000Tsh which was used to approximate the annual income to 5,490,000Tsh per year. The analysis on the profitability of bodaboda business as presented in Table 5 shows that the Net present value for the bodaboda business in five years is 8,494,920Tsh and the Benefit Cost Ratio of the bodaboda business in five years is 2.08 . The decision rule is to accept the project with NPV and BCR $\geq 1$. With the findings by this study; Both NPV and BCR show that bodaboda business is profitable and worth being undertake. By using the formula below NPV and BCR is calculated and presented in Table 3.9

$$
\begin{gathered}
B C R=\frac{\text { Sum of the Discounted Benefits }}{\text { Sum of the Discounted Costs }} \\
N P V=\sum_{i=1}^{n} \frac{B_{i}-C_{i}}{(1+r)^{i}}
\end{gathered}
$$

\begin{tabular}{|c|c|c|c|c|c|c|}
\hline Items description & Year 0 & Year 1 & Year 2 & Year 3 & Year 4 & Year 5 \\
\hline Initial Capital & $(1,500,00)$ & & & & & \\
\hline $\begin{array}{c}\text { Average Repair and } \\
\text { maintenance cost }\end{array}$ & & 306000 & 306000 & 306000 & 306000 & 306000 \\
\hline $\begin{array}{l}\text { Average Operating } \\
\text { Costs }\end{array}$ & & 1830000 & 1830000 & 1830000 & 1830000 & 1830000 \\
\hline Total Costs & & 2136000 & 2136000 & 2136000 & 2136000 & 2136000 \\
\hline DF (20\%) & 1.00 & 0.83 & 0.69 & 0.58 & 0.48 & 0.40 \\
\hline Discounted Costs & $1,500,000$ & 1772880 & 1473840 & 1238880 & 1025280 & 854400 \\
\hline Sum (A) & \multicolumn{6}{|c|}{7865280} \\
\hline $\begin{array}{c}\text { Average Annual } \\
\text { Revenue }\end{array}$ & & 5,490000 & $5,490,000$ & $5,490,000$ & $5,490,000$ & $5,490,000$ \\
\hline $\begin{array}{c}\text { Discounted Revenue } \\
\text { at } 20 \% \\
\end{array}$ & & 4,556700 & 3788100 & 3184200 & 2635200 & $2,196,000$ \\
\hline Sum (B) & \multicolumn{6}{|c|}{16360200} \\
\hline BCR & & 2.08 & & & & \\
\hline $\begin{array}{c}\text { Disc Net Cash } \\
\text { outflow }\end{array}$ & $(1,500,00)$ & 2783820 & 2314260 & 1945320 & 1609920 & 1341600 \\
\hline NPV & \multicolumn{6}{|c|}{ 8,494,920Tsh } \\
\hline
\end{tabular}

Table 3.9. Bodaboda business NPV (in Tsh) and BCR over five years at $20 \%$ discount rate 
Luvinga, K. C., \& Kilasara, S. A. (2020). The Financial Implications of Bodaboda Transport Business Among Youths In Arusha- Cost Benefit Analysis. Advances in Social Sciences Research Journal, 7(4) 177-185.

Under the decision rule to accept the projects with positive NPV and BCR greater than 1, the Bodaboda business signified profitability and worth being undertaken since it have the benefit cost ratio (BCR) of 2.08 and the Net present Value (NPV) 8,494,920 Tsh in five years durations.

\section{Discussion}

The findings show that the bodaboda business is among informal sectors which do not require too high initial capital simply because youths can choose either to hire a Motocycle for the business or buy it himself.

The findings on the aggregate of the fixed investment cost, daily operating expenses are still low than the revenue generated from daily operations of the bodaboda business. In general the findings on bodaboda business profitability as presented through positive Net Present Value (NPV), Benefit Cost ratio (BCR), and Profitability index shows that the business is profitable and favors youth's livelihood through increased financial income. This suggests that there should be efforts to formalize and manage the business so that the youths can easily engage and operate without any interference and limitations,

\section{CONCLUSION AND RECOMMENDATIONS}

This paper has examined the profitability of the motorcycle transport business among youths engaging a business. It has been established that bodaboda operations serve as an alternative means for youths livelihood which contributes to income of the operators. The findings further shows that the bodaboda business is profitable as signified by the positive Net present Value as well as the Benefit cost ratio of 2.08. There is a need for further research on informal sectors governance and sustainability so that more youths can secure and operate safely in the business.

\section{RECOMMENDATIONS}

Based on the findings from the study it is recommended that the government authorities and all key stakeholders should regulate, and support the implementation of bodaboda bussiness through formalization of bodaboda associations, assurance of financial supports and capacity building to youths who engage or willing to engage in the business.

The study also recommend that youths engaging in the business should formalize their business, seek for training on safe driving based on the guiding regulations and rules, financial management training as well as effective customer care and management so as to maximize their business potentiality.

\section{References}

Booth, D., Hanmer, L., and Lovell, E. (2000) Poverty and Transport; A report prepared for the World Bank in collaboration with DFID

Howe, J., \& Davis, A. (2002). Bodaboda-Uganda's rural and urban low-capacity transport services. Urban Mobility for All, Lisse: AA Balkema Publishers, 235-240.

Kageha, Z. Agesa, P. (2006) Bodaboda Operations in Vihiga: Are they blessing or a curse, Masinde Muliro University of science and Technology

Kumar, A. (2011) Understanding the emerging role of Motorcycles in Africa cities; A political economy perspectives 
Malmberg-Calvo, C. (1994) Case Study on Intermediate Means of Transport: Bicycles and Rural Women in Uganda, Washington DC: World Bank.

Malmberg-Calvo, C. (1994) 'Case Study on the Role of Women in Rural Transport: Access of Women to Domestic Facilities', SSATP Working Paper 11, Washington, DC: World Bank and Economic Commission for Africa.

Mbugua, C. (2011) the effects of the motorcycle transport revolution on the economic growth of kenya,

Nyachieo, G. (2013), Creating employment through Transport; The youth and the Motorcycles (Bodaboda) in Kenya

Olvera D.L., Plat D., Pochet P., 2007, Household transport expenditure in Sub-Saharan African cities:

Measurement and Analysis, Journal of Transport Geography.

Salum, Y. (2015), Informal Transport Sector and Youth Employment in Tanzania; A study of Boda boda employment in Kiteto District, Unpublished dissertation, University of Dodoma.

Summers, M. (2012).Stock, Rwanda Youth and struggle for adulthood, Athens university of Georgia press.

World Bank. (2002). Cities on the Move: A World Bank Urban Transport Strategy Review. Washington D.C.: World Bank Publications 